\title{
O ESTADO ENDIVIDADO: NA ENCRUZILHADA ENTRE O DESENVOLVIMENTO ECONÔMICO E OS DIREITOS SOCIAIS
}

\section{Willame Parente Mazza}

Pós-Doutor pela Faculdad de Derecho de Sevilla - Espanha. Doutor em Direito pela Universidade do Vale do Rio dos Sinos (UNISINOS-RS), com período de pesquisa (doutorado "sanduíche") na Faculdade de Direito da Universidade de Coimbra. Mestre em Direito com ênfase em Tributário, pela Universidade Católica de Brasília (UCB), Especialização em Direito Tributário e Fiscal, Especialização em Direito Público e Especialização em Controle na Administração Pública. Bacharel em Direito e Engenharia Civil. Auditor Fiscal da Fazenda Estadual do Estado do Piauí, Professor adjunto no curso de Direito da Universidade Estadual do Piauí (UESPI). Membro da Rede de Pesquisa Estado \& Constituição (REPE\&C) e do Grupo de pesquisa "Terceiro Setor e Tributação" UCB-DF.

\section{SUMÁRIO}

Introdução - 1. Do estado social ao estado endividado: um caminho sem volta? -2 . O novo paradigma financeiro, a prioridade das políticas monetárias e o "sufoco" das políticas fiscais - 3. A prevalência da austeridade fiscal e o rebaixamento democrático -4 . O constitucionalismo social e a necessidade de seguir o agir político-estatal - 5 . A Constituição de 1988 entre o novo paradigma financeiro, o endividamento público e as contrarreformas: $5.1 \mathrm{~A}$ seguridade social e o endividamento público: para onde foram os recursos orçamentários?; 5.2 Uma visão dos gastos com proteção social - 6. O desenvolvimento econômico e a progressão social: muito além da austeridade, dos ajustes fiscais e da redistribuição de renda - Considerações finais Referências. 


\section{INTRODUÇÃO}

$\mathrm{Na}$ tentativa de reduzir os males da desigualdade, as constituições democráticas apresentam seu principal papel consolidador dos direitos sociais da cidadania. O constitucionalismo no Estado social foi o que mais desenvolveu a vocação das constituições modernas de estruturar a vida econômica e social. Essa nova forma de integração social e econômica se incorpora nas constituições, marcando o Estado social.

O Estado passou a ter novas responsabilidades e inclusão social que culminaram na necessidade de despesas, crises e um maior endividamento, passando por um período de transição do Estado fiscal ao "Estado endividado", acumulando dívidas que, na maioria das vezes, não tiveram a contrapartida para o financiamento dos direitos conquistados no constitucionalismo social.

A questão do endividamento público e o financiamento dos recursos necessários à sustentabilidade dos direitos sociais sempre geraram polêmicas devido à falta de transparência nas contas públicas e na prioridade dos recursos, que não convergiam para os objetivos e fundamentos prescritos no texto constitucional.

Após os anos 1970, com a ascensão neoliberal, um novo paradigma financeiro prevaleceu, com foco na política monetária e programas de austeridade, em função do controle dos gastos públicos, questionando-se, muitas vezes, o excesso de democracia com os recursos previstos nas constituições democráticas. Tais medidas de controle são colocadas como essenciais para o desenvolvimento econômico e o retorno ao bem-estar social. No entanto, muitos dos instrumentos utilizados como estabilizadores, como os ajustes fiscais e reformas, são postos em questionamentos devido à prioridade ao sistema financeiro em detrimento dos direitos sociais garantidos nas constituições. Argumenta-se que as alterações legislativas são seletivas a fim de proteger o sistema da dívida pública, distorcendo o equilíbrio entre os sistemas financeiros, tributários e a constituição federal.

Nesse sentido, pretende-se discutir as transformações do Estado, com a passagem ao constitucionalismo social dentro de um contexto de disputa de recursos e de endividamento público. Notadamente passa-se pela questão democrática e seu financiamento, assim como os gastos com a seguridade social, as contrarreformas, o papel da austeridade e as alterações legislativas estruturais no âmbito das constituições democráticas. Por fim, traçam-se ideias para a questão do desenvolvimento econômico e o papel do Estado, da inovação e do mercado nesse processo, necessário para a redistribuição dos recursos oriundos desse desenvolvimento, que vai muito além dos estabilizadores, da austeridade e de uma análise solitária dos mecanismos de redistribuição de renda. 


\section{DO ESTADO SOCIAL AO ESTADO ENDIVIDADO: UM CAMINHO SEM VOLTA?}

Nas transformações pelas quais o Estado vem passando, insere-se como elemento decisivo a busca do equilíbrio entre os direitos individuais e os de igualdade, com o crescimento econômico imbricado em uma relação não excludente. Chega-se ao Estado social após as falhas das promessas liberais, que não confirmaram a tese de que, deixando a economia e a sociedade independentes e confiadas às leis naturais do mercado, proporcionariam aos indivíduos condições de liberdade iguais a todos, com melhores condições de vida.

O Estado social surge como direito de compromisso no contexto de justiça social e de reivindicações igualitárias, pelo que não se autonomiza do seu ambiente liberal e do núcleo econômico do capitalismo, reconhecendo que não se renegam suas origens, mas "domestica suas pulsões de morte" diante dos fatores que impulsionaram uma mudança constitutiva do projeto inaugural do "Estado liberal de Direito da burguesia revolucionária em luta contra o Estado Aristocrático-absolutista do Ancién Règime”. Assim, o Estado social convive e incorpora uma relação de inclusão e exclusão, sem se livrar dos âmbitos de individualismo possessivo, para, como objetivo, promover a realização desse Estado com a inclusão social por meio de políticas públicas, mesmo aceitando um certo nível de exclusão ${ }^{1}$.

No mesmo sentido, destaca Garcia-Pelayo² que o Estado social não significou uma ruptura com o Estado liberal de direito, mas um "intento de adaptação das notas clássicas do Estado de Direito ao seu novo conteúdo e às suas novas condições ambientais”. Assim, os valores básicos do Estado liberal de direito liberdade individual, igualdade, propriedade privada, segurança jurídica - são valores não negados pelo Estado social, uma vez que é dado um novo significado, que complementa com outros critérios axiológico-políticos.

Diante de novas tarefas, responsabilidades e necessidades de inclusão do Estado social - advindas da modificação da economia, da modernização social e dos riscos -, surgiram custos para a sua implementação associados às crises e problemas de financiamento, como a crise dos anos 1970, que permitiu a viragem neoliberal e a transformação da relação entre o setor financeiro e o setor produtivo, com a prioridade da política monetária sobre a fiscal. Houve o questiona-

1 MORAIS, José Luis Bolzan. Entre o estado social e a transformação social: mudar para não mudar. In: COUTINHO, Adalcy et al. (org.). Liber Amicorum: homenagem ao prof. doutor António José Avelãs Nunes. Coimbra: Coimbra Editora, 2009. p. 527-528.

2 GARCÍA-PELAYO, Manuel. As transformações do Estado contemporâneo. Tradução de Agassiz Almeida Filho. Rio de Janeiro: Forense, 2009. p. 41-42. 
mento se as finanças públicas do capitalismo democrático sofreram pelo excesso de democracia.

No entanto, como lembra o sociólogo alemão Wolfgang Streeck ${ }^{3}$, o Estado teve suas crises financeiras não só em função das despesas sociais da época, mas, sobretudo, pelo endividamento e crescimento da dívida pública. O Estado passa por um período de transição do Estado fiscal ao Estado endividado, no qual salda cada vez mais suas despesas por empréstimo, acumulando dívidas para cujo financiamento tem de utilizar uma porcentagem cada vez maior de suas receitas. Dívida esta mantida primordialmente para alimentar o sistema financeiro e a nova fase do capitalismo, na transição do produtivo ao financeiro.

Em uma análise retrospectiva da evolução da crise orçamental no mundo, não se tem qualquer relação do crescimento do endividamento com o cumprimento das reivindicações democráticas consignadas nos textos constitucionais. Com efeito, se houve reivindicações, estas foram feitas pelos grandes bancos e indústrias, que, após a crise de 2008, foram salvos por meio de investimentos financeiros pelo Estado, a fim de não deixar nenhuma instituição financeira falir. Como diz o professor de Coimbra, Avelãs Nunes ${ }^{4}$, é um "capitalismo sem falências", em que nenhuma instituição financeira poderia "quebrar". Essa política de financiamento das instituições financeiras absorveu, por exemplo, em 2009, um valor correspondente a $80 \%$ do PNB nos EUA e no Reino Unido, à custa do Estado social.

Conforme o economista francês Jean-Paul Fitoussi ${ }^{5}$, após a Segunda Guerra Mundial, não há comprovação válida de que a busca da coesão social seria um obstáculo à eficácia econômica, e, por toda parte, mas em formas diferentes, a democracia impôs instituições promotoras de solidariedade. Foi verificado que sociedades mais solidárias não são as que têm pior desempenho econômico. Assim, a abertura dos países às trocas internacionais foi acompanhada de um aumento do poder dos sistemas de proteção social e que, conforme o autor, não é essa abertura que se questiona, mas "o discurso retórico de legitimação do capitalismo dominador que considera que a democracia e a política são obstáculos ao desenvolvimento, em contradição flagrante com os factos".

3 STREECK, Wolfgang. Tempo comprado: a crise adiada do capitalismo democrático. Tradução de Marian Toldy e Teresa Toldy. Lisboa: Actual, 2013. p. 87.

4 NUNES, António José Avelãs. Apontamento sobre a origem e a natureza das políticas de austeridade. In: FERREIRA, Eduardo Paz (coord.). A austeridade cura? A austeridade mata? Lisboa: AADFL, 2014. p. 126-128.

5 FITOUSSI, Jean-Paul. A democracia e o mercado. Tradução de Paulo Pedroso. Lisboa: Terramar, 2005. p. 8-11. 


\section{O NOVO PARADIGMA FINANCEIRO, A PRIORIDADE DAS POLÍTICAS MONETÁRIAS E O “SUFOCO” DAS POLIITICAS FISCAIS}

No período entre 1940 e 1970, aproximadamente, chamado "trinta anos gloriosos", no qual os países conheceram a melhor fase do desenvolvimento econômico e social, prevaleceram as ideias de John Maynard Keynes, em que o Estado procurava conciliar o problema da desigualdade inerente às sociedades capitalistas, na busca por maior justiça social, com o desenvolvimento econômico. De fato, a desigualdade de rendimento não favorecia o desenvolvimento da riqueza, e Keynes procurou equacionar o progresso social com a eficácia econômica como condição de possibilidade para a democracia. Permitia-se, inclusive, o déficit público, mas com foco na garantia do pleno emprego, e não um déficit, como o atual, que garanta a remuneração do capital financeiro em detrimento do capital produtivo. Embora Keynes não seja um paradigma hegemônico entre os economistas, sua teoria foi a base de aplicação das políticas monetárias e fiscais orientadas para o pleno emprego e que teve êxito por um longo período.

A política monetária apresenta-se como principal instrumento macroeconômico para estabilização, controle da inflação e redução dos números da dívida, em total desequilíbrio com as políticas fiscais. Olivier Blancard ${ }^{6}$, economista-chefe do FMI, na conferência "Repensar la política macroeconômica", critica o uso da política monetária com o objetivo primordial de estabilização da inflação, que utiliza como principal instrumento as taxas de juros. Afirma que a política monetária necessita ir além da estabilidade financeira e do combate à inflação, e que a macroeconomia teria muito mais do que um só instrumento para implementá-la. Por outro lado, conforme as lições de Keynes, após o resultado da grande depressão, nos anos de 1940 a 1970, conhecidos como os "30 anos gloriosos", as políticas monetárias e fiscais mantinham uma relação equilibrada, e a política fiscal se apresentava como principal instrumento da política macroeconômica.

Assim, após a década de 1970, nasceu um novo paradigma de expansão financeira, não mais calcado na produção, em que se convertia o capital monetário em mercadorias, bens e serviços, tendo um arcabouço jurídico que garantia a expansão do capital. O novo paradigma assentava-se na acumulação fundada nos processos de capitalização financeira da expansão do capital, o qual demanda normas jurídicas que permitam a sua expansão contínua, sem a necessidade de

6 BLANCHARD, Olivier; DELl'ARICCIA, Giovanni; MAURO, Paolo. Repensar la política macroeconômica. Revista de Economía Institucional, Bogotá, v. 12, n. 22, p. 66, 2010. Disponível em: http://www.economiainstitucional.com/pdf/no22/oblanchard22.pdf. Acesso em: 24 fev. 2015. 
conversão em mercadorias e multiplicando a riqueza exclusivamente por meio de acordos financeiros?

Ascendia o processo de financeirização, com a subordinação do capital produtivo ao financeiro, a desvalorização dos financiamentos em investimentos produtivos e na inovação, o que, como consequência, refletirá na baixa criação de empregos e na pressão para os cortes salariais e os direitos sociais ${ }^{8}$. Passava-se da fase keynesiana, com foco no pleno emprego, para o que se chamou de "contrarrevolução monetarista", com a ascensão neoliberal, do capitalismo financeirizado, com foco na estabilização, controle inflacionário e a desvalorização da política de pleno emprego.

Não se quer afirmar a desnecessidade de mecanismos de estabilização, que garantam o crescimento econômico com o progresso social, mas, sim, denunciar o "mito da estabilização" seletiva, que reafirma o desequilíbrio entre as políticas monetárias, fiscais e cambiais, a aumentar o endividamento dos países e a conduzir o rebaixamento democrático, o qual faz prevalecer a razão técnica sobre a razão política.

Existe, portanto, um discurso ideológico que se sobrepõe ao bom funcionamento da democracia nas escolhas orçamentais, que reflete os valores da sociedade. Observa-se isso com os "mitos de estabilização" e programas de austeridades que são impostos aos cidadãos - como bem colocado pelo francês Marc Leroy em seu estudo de sociologia financeira - com o objetivo de equacionar o problema da decisão financeira, como estando determinado por constrangimentos que não deixam lugar a escolhas políticas. Dessa maneira, as elites políticas e econômicas impõem suas escolhas pela manipulação ideológica da racionalidade cognitiva dos cidadãos .

\section{A PREVALÊNCIA DA AUSTERIDADE FISCAL E O REBAIXAMENTO DEMOCRÁTICO}

Dessa forma, em função das crises, no caminho da estabilidade constante e controle inflacionário, diversos países, em especial na Europa, tomaram medidas

7 MASSONETTO, Luis Fernando. O direito financeiro no capitalismo contemporâneo: a emergência de um novo padrão normativo. 2006. 104f. Tese (Doutorado em Direito) - Universidade de São Paulo, São Paulo, 2006.

8 NUNES, António José Avelãs. O aprofundamento da crise estrutural do capitalismo e a integração capitalista europeia. Empório do Direito, [s.l.], 4 abr. 2015. Disponível em: http://emporiododireito.com. br/o-aprofundamento-da-crise-estrutural-do-capitalismo-e-a-integracao-capitalista-europeia-por-antonio-avelas-nunes/. Acesso em: 5 abr. 2014.

9 LEROY, Marc. Sociologia da decisão financeira pública. In: SANTOS, António Carlos dos; LOPES, Cidália Maria da Mota Lopes (coord.). Fiscalidade: outros olhares. Porto: Vida Econômica, 2013. p. 73-74. 
drásticas, com planos de austeridade para reduzir os números da dívida pública e o salvamento de bancos, o que levou a "sufocar" os direitos sociais consagrados no constitucionalismo democrático. Tais medidas, comprovadamente, não surtiram os efeitos desejados, o que deveria servir para lições futuras.

Para Avelãs Nunes ${ }^{10}$, as políticas de austeridade foram instrumentos aproveitados pelas "crises" para obrigar os povos a pagar as dívidas do capital financeiro, desmontando o Estado social pela diminuição da produção, aumento do desemprego, baixa dos salários reais, redução de direitos sociais, asfixia financeira dos sistemas públicos de segurança social e supressão dos preceitos fundamentais definidores do Estado democrático de direito.

A austeridade beneficia uma pequena minoria do capital financeiro, além de não favorecer o desenvolvimento econômico, e sim, o aumento da desigualdade, que retrai o crescimento, prejudica a distribuição de renda, o consumo, além disso, enfraquece o investimento, com instabilidades financeiras, econômicas e políticas. Avelãs Nunes denuncia, em relatório da OIT $^{11}$, de 24.01.2012, a política de deflação salarial realizada pela Alemanha, que, além de reduzir o consumo, conduziu a um aumento das desigualdades de rendimentos nunca antes registrado.

Em Portugal, foram impostas políticas de austeridade de caráter recessivo e reformas estruturais, que provocaram uma grande desregulação do mercado de trabalho, privatizações de empresas públicas ou de participações públicas em empresas estratégicas, aumento de impostos, redução de salários, pensões e de prestações sociais. Como consequência dessas medidas, houve um empobrecimento vertical da população, com redução do PIB superior a $6 \%$ e uma taxa de desemprego que variou de $12,9 \%$ a $17,8 \%$ entre 2011 e 2013, com queda no investimento, sem redução do déficit, pois a dívida pública continuou subindo de 108,3\% do PIB (2011) para $127,2 \%$ no final do primeiro trimestre de $2013^{12}$.

Para o Nobel de economia Joseph Stiglitz ${ }^{13}$, a austeridade falhou e vem levando os estados da União Europeia à recessão, com altos patamares de desemprego e um fraco crescimento do PIB per capita. Não se pode atribuir sucesso a

10 NUNES, António José Avelãs. Apontamento sobre a origem e a natureza das políticas de austeridade, cit., p. 127.

11 NUNES, António José Avelãs. Apontamento sobre a origem e a natureza das políticas de austeridade, cit., p. 130-131.

12 ROMÃO, António. A crise "mata", a austeridade "enterra". In: FERREIRA, Eduardo Paz (coord.). A austeridade cura? A austeridade mata? Lisboa: AADFL, 2014. p. 255-258.

13 STIGLITZ, Joseph. "Ajuste fiscal”? Por que não seguir a Europa. Tradução de Mariana Bercht Ruy. [sS.1.], 12 nov. 2014. Disponível em: http://brasildebate.com.br/ajuste-fiscal-por-que-nao-seguir-a-europal. Acesso em: 12 nov. 2014. 
uma política em função de alguns momentos de recuperação econômica, esquecendo os danos que essa mesma política vem causando ao bem-estar das pessoas e à própria economia.

Como consequência dessas medidas de austeridade, a democracia é enfraquecida, tendo em vista que, em muitos países, os cidadãos votam por alguma mudança política, mas as decisões são tomadas fora do escopo em que são feitas suas escolhas. Na Europa, por exemplo, o pacto orçamental autoriza medidas pela Comissão Europeia ou pelo Tribunal de Justiça da União Europeia sem a intervenção dos parlamentos nacionais e dos sistemas judiciários nacionais, o que reflete em desvirtuamento do poder democrático local. No Brasil, várias medidas de ajustes fiscais e alterações legislativas foram traçadas em função ou por influência de organismos internacionais, por exemplo, o FMI, em suas "cartas de intenções".

Com efeito, os programas de austeridade mitigam a democracia. Com a transição do Estado fiscal ao Estado endividado, há um deslocamento da política, que, cada vez mais, sistematiza a captura do poder público dos próprios governos. Surgem os credores, os quais passam a influenciar na política estatal a fim de assegurar suas reivindicações, tornando-se uma segunda classe de titulares de direitos, além dos cidadãos ${ }^{14}$.

Dessa forma, a austeridade passa a ser um instrumento para garantir a confiança dos credores, a qual, como afirma Wolfgang Streeck, exige dos governos que convençam ou obriguem os seus cidadãos a diminuir suas reivindicações ao orçamento do Estado, em favorecimento do sistema financeiro. Por conseguinte, Streeck demonstra um modelo de Estado endividado menos democrático, no qual se submete cada vez mais a política dos governos à disciplina dos mercados financeiros, por meio de um deslocamento da política estatal, que passa a responder, tanto quanto possível, simultaneamente, a dois "submundos em conflito": o "povo do Estado" de um lado, e o "povo do mercado" de outro. O primeiro são cidadãos que, por meio do projeto de Estado democrático de direito, contribuem com impostos, ao mesmo tempo que, ligados a um Estado que faz valer os seus direitos fundamentais inalienáveis, recebem em contrapartida a prestação de serviços de interesse geral para a garantia dos seus direitos sociais. O segundo, "povo do mercado", está ligado ao Estado por meio de contratos, como investidores, com direitos privados perante o Estado, que não se baseiam na constituição, mas no direito civil. Assim, o Estado endividado pode esperar lealdade do seu povo “(...) enquanto dever cívico, enquanto no que diz respeito ao povo do mercado

14 STREECK, Wolfgang. Tempo comprado: a crise adiada do capitalismo democrático, cit., p. 127. 
tem de procurar conquistar a sua confiança, pagando devidamente as suas dívidas e provando que poderá e quererá fazê-lo também no futuro"15.

\section{O CONSTITUCIONALISMO SOCIAL E A NECESSIDADE DE SEGUIR O AGIR POLÍTICO-ESTATAL}

Esse modelo foi marcado pelo constitucionalismo social, que teve maior valorização no desenho do Estado social, no segundo pós-guerra, em um processo de reconstitucionalização na Europa, que definiu o lugar das constituições, fundado na crença de que se poderia construir uma sociedade justa e solidária com a inclusão da questão social e a erradicação da pobreza, que, por conseguinte, tornou-se característica da Constituição brasileira, com a consolidação do processo de redemocratização e alicerçada em um amplo catálogo de direitos fundamentais, com ênfase nos direitos econômicos e sociais, baseada nas experiências europeias da segunda metade do século passado. O dirigismo passa a ser a característica típica das constituições do Estado social que procura definir uma pauta para a sociedade e o Estado, por meio de normas programáticas.

Assim, as constituições sociais reconhecem a questão social da igualdade ou direitos econômicos, sociais e culturais que trazem a estrutura do constitucionalismo dirigente, o qual tem no texto constitucional normas determinantes do agir político-estatal. É no constitucionalismo dirigente que aparece o papel transformador social, que define fins e objetivos para o Estado e a sociedade. Nesses termos que, como afirma Eros Roberto Grau ${ }^{16}$, a Constituição do Brasil não é um mero "instrumento de governo", "enunciador de competências e regulador de processos, mas, além disso, enuncia diretrizes, fins e programas a serem realizados pelo Estado e pela sociedade. Não compreende tão somente um 'estatuto jurídico do político', mas, sim, um 'plano global normativo' da sociedade e, por isso mesmo, do Estado brasileiro”. Assim, não é uma Constituição que substitui a política, mas que sujeita a política à fundamentação constitucional, ou seja, vincula as políticas públicas a ela.

Com efeito, os princípios fundamentais da Constituição de 1988 são determinantes para toda a ação governamental e as interpretações do texto constitucional. A política fiscal do Estado tem, portanto, uma diretriz, independente do governo, estabelecida na Constituição, na qual os fundamentos da República Fe-

15 STREECK, Wolfgang. Tempo comprado: a crise adiada do capitalismo democrático, cit., p. 129-131.

16 GRAU, Eros Roberto. Resenha do prefácio da $2^{\text {a }}$ edição. In: COUTINHO, Jacinto Nelson de Miranda (org.). Canotilho e a constituição dirigente. São Paulo: Renovar, 2005. 
derativa do Brasil (art. $1^{\circ}$ ) são as bases para toda ação estatal e ponto de partida para sua implementação, que tem, como no art. $3^{\circ}$, os objetivos ou o ponto de chegada dessas políticas.

\section{A CONSTITUIÇÃO DE 1988 ENTRE O NOVO PARADIGMA FINANCEIRO, O ENDIVIDAMENTO PÚBLICO E AS CONTRARREFORMAS}

Desde a Constituição de 1988, sempre houve a disputa de recursos entre o financiamento dos direitos sociais e o sistema financeiro. A Constituição assentou os direitos sociais como categoria essencial, no mesmo plano de importância dos direitos civis e políticos, garantindo o financiamento desses direitos em uma espécie de orçamento mínimo social, quando destaca os recursos direcionados para saúde, educação, erradicação da pobreza, fundo de amparo ao trabalhador, meio ambiente e seguridade social.

A Constituição de 1988 reflete um déficit de eficácia e as dificuldades para concretização de uma Constituição dirigente, num contexto de profunda "transformação, em sentido regressivo - lembre-se das propostas neoliberais, dos planos de reformas do Estado, das sugestões de flexibilização dos direitos e garantias sociais etc. - do Estado Social" ${ }^{17}$. Tais flexibilizações, implementadas pelos planos de ajustes e as políticas fiscais, permitiram a modificação das finalidades e objetivos da Constituição, para atender aos ditames neoliberais e financeiros do mercado.

As Constituições sociais enfrentam obstáculos para a sua concretização, o que impede o seu cumprimento total. Na verdade, como afirma Gilberto Bercovici ${ }^{18}$, o núcleo "emancipatório das Constituições sociais foi, na prática, suspenso", evidenciando-se com a crise econômica, a partir da década de 1970, e a contrarrevolução "neoliberal conservadora", que não se limita mais a "suspender ou bloquear as cláusulas sociais das Constituições, mas busca a extirpação formal do texto constitucional”.

Esse panorama confronta com as características do caráter inovador do constitucionalismo brasileiro de 1988, que trouxe a ampliação do catálogo de direitos fundamentais e inovações procedimentais, no conjunto de ações constitu-

${ }_{17}$ MORAIS, José Luis Bolzan. O Estado e seus limites: reflexões iniciais sobre a profanação do Estado social e a dessacralização da modernidade. In: OLIVEIRA NETO, Francisco José de et al. Constituiçãa e estado social: os obstáculos à concretização da Constituição. Coimbra: Coimbra Editora; São Paulo: RT, 2008. p. 180.

18 BERCOVICI, Gilberto. Soberania e Constituição: para uma crítica do constitucionalismo. São Paulo: Quartier, 2013. p. 321. 
cionais, "desde aquelas de proteção e promoção das garantias às de controle de constitucionalidade e à ampliação da legitimidade ativa e revisão do modelo federativo" ${ }^{19}$. Destaca-se, ainda, o Estado Democrático de Direito como opção da República Federativa do Brasil, com o conteúdo transformador da realidade, o que diferencia dos modelos que a precediam e que "limitavam-se a um rearranjo das condições sociais" 20 .

Nesse novo modelo do Estado Democrático de Direito, com características inéditas, incorporou-se, de forma efetiva, a questão da igualdade, a ser garantida por meio do asseguramento jurídico das condições mínimas de vida ao cidadão, que traz como núcleo o princípio-guia da dignidade da pessoa humana ${ }^{21}$.

A Constituição Federal de 1988 consignava no texto original uma economia de mercado com forte planejamento estatal, nacionalista e favorecia a descentralização de receitas, em um sentido oposto à centralização exercida na ditadura militar, por meio da repartição de competências com os entes subnacionais, financiando suas demandas, e, de forma cooperativa, com a repartição a Estados e municípios, o que favorecia uma maior autonomia financeira.

No entanto, já a partir da década de 1990, essa maior autonomia financeira era considerada um entrave aos planos de metas fiscais, uma vez que se alegava o engessamento da economia pela Constituição.

Assim, tomando o período a partir de 1994, com a estabilização, foram feitas contrarreformas, orientando transformações na Constituição Federal, que dificultaram sua concretização, transferindo recursos ao mercado financeiro e favorecendo a tutela da renda de capital. Como lembra Gilberto Bercovici22, priorizou-se a "Constituição dirigente invertida", que traz a cisão entre a constituição financeira e econômica, retratada pelas políticas neoliberais de ajuste fiscal e vista como positiva para a credibilidade e confiança do país junto ao sistema financeiro. Por outro lado, a Constituição dirigente das políticas públicas e dos direitos sociais é entendida como prejudicial aos interesses do país, pois

19 MORAIS, José Luis Bolzan. O Brasil pós-1988: dilemas do/para o Estado constitucional. In: SCAFF, Fernando Facury (org.). Constitucionalizando direitos: 15 anos da Constituição brasileira de 1988. Rio de Janeiro: Renovar, 2003. p. 105.

${ }^{20}$ MORAIS, José Luis Bolzan. O Brasil pós-1988: dilemas do/para o Estado constitucional, cit., p. 105.

21 MORAIS, José Luis Bolzan. O Brasil pós-1988: dilemas do/para o Estado constitucional, cit., p. 107.

22 BERCOVICI, Gilberto; MASSONETTO, Luís Fernando. A Constituição dirigente invertida: a blindagem da Constituição financeira e a agonia da Constituição económica. Boletim de Ciências Econômicas, Coimbra, v. 49, 2006. 
torna-se um empecilho ao desenvolvimento, causadora dos déficits públicos e crises econômicas.

Com a estabilização econômica, durante o plano real, houve um crescimento das taxas de juros - que atraíam o capital estrangeiro - e, consequentemente, da dívida pública (ultrapassou 50\% do PIB), motivando os ajustes fiscais, baseados no tripé ortodoxo dos câmbios flutuantes, superávit primário e metas de inflação, a fim de reduzir os números da dívida.

Com os ajustes fiscais, o governo federal reverteu a descentralização de receitas trazidas na Constituição Federal. Explorou as contribuições sociais para voltar à concentração de receitas, uma vez que esses tributos não eram repartidos aos estados e municípios. Em média, de 1995 a $2013^{23}$, a União concentrou 70\% das receitas, enquanto os Estados 25\% e municípios 5\%. Os Estados também, em função da elevação das taxas de juros como um dos instrumentos de sustentação do Plano de Estabilização, foram forçados a reestruturar os bancos estaduais e a renegociar as dívidas com a União, com a imposição de várias exigências nessas renegociações, contrariando a autonomia dos entes subnacionais.

Criou-se a DRU (Desvinculação da Receita da União), por emenda constitucional, sucessora do Fundo Social de Emergência (EC n. 1/1994), e que tira a obrigatoriedade constitucional de os entes públicos alocarem recursos nas áreas da saúde e seguridade social, considerando-se uma verdadeira fraude à Constituição ${ }^{24}$.

Outra alteração estrutural na constituição foi a EC n. 95 (Novo Regime Fiscal), de 2016, que não condiz com o projeto de Estado e sociedade estabelecido na constituição dirigente. Há um foco seletivo nas despesas públicas, deixando de fora as despesas financeiras, juros e amortizações da dívida. Assim, em função das altas taxas de juros, o Brasil, desde 2003, apresentou déficit orçamentário (nominal), quando se incluem despesas com juros. Já o resultado primário, que é o foco da emenda constitucional, apresentou superávit em quase todos os anos (receitas superaram as despesas). Conforme estudo do DIEESE ${ }^{25}$, houve compatibilidade entre esses indicadores no período de 1998 a 2008 e 2010 a 2011 e, nos períodos de déficit, deram-se em função da crise internacional, das medidas anti-

${ }^{23}$ RECEITA FEDERAL. Brasília, DF, 2015. Disponível em: www.receita.fazenda.gov.br. Acesso em: 10 abr. 2015.

24 A DRU será explicada com mais detalhes no item 5.1.

25 DEPARTAMENTO INTERSINDICAL DE ESTATÍSTICA E ESTUDOS ECONÔMICOS (DIEESE). PEC n. 241/2016: o novo regime fiscal e seus possíveis impactos. Disponível em: https://www.dieese.org.br/notatecnica/2016/notaTec161novoRegimeFiscal.pdf. Acesso em: 20 out. 2016. 
cíclicas adotadas pelo governo e, notadamente, da queda das receitas, justificada, entre outros motivos, pela própria crise econômica e as desonerações fiscais concedidas pelos governos. Ou seja, há um discurso distorcido e seletivo para o ajuste nas despesas públicas, tirando o foco das despesas financeiras, justificadoras do crescimento da dívida pública.

Quanto ao sistema tributário, este passou a ser um mero instrumento para os ajustes fiscais, descaracterizando o papel inicial que tinha na Constituição federal, no sentido da descentralização das receitas, justiça fiscal e fortalecimento da Federação. Tais medidas se aprofundaram em razão das crises econômicas e fiscais e da ameaça permanente de deflagração de um processo hiperinflacionário, associada à necessidade do governo federal de encontrar soluções para o financiamento das políticas sociais estabelecidas na Constituição ${ }^{26}$, já que muitos dos recursos sofreram desvirtuamento de suas finalidades, como já exposto.

Diante de todas essas alterações acima, que consagram a questão da "constituição dirigente invertida" e uma nítida prioridade aos ajustes fiscais sem responsabilidade social, verificam-se medidas alheias aos objetivos e fundamentos da constituição federal que direcionam ao "andar de cima".

O sistema tributário e a legislação infraconstitucional, que poderiam diminuir esse desequilíbrio na distribuição de renda e alinhar os resultados de fato aos preceitos fundamentais, aumentam cada vez mais a desigualdade de renda e social, o que se percebe na regressividade do sistema tributário e a oneração desproporcional aos cidadãos de menor poder aquisitivo e os assalariados, que são os que mais financiam o fundo público, responsáveis por $67,03 \%$, em relação a 2007, por exemplo, das receitas arrecadadas pela União, Estados, Distrito Federal e municípios, considerando a tributação sobre o consumo e a tributação sobre a renda dos trabalhadores, incluindo a contribuição previdenciária de empregadores e servidores públicos.

Essa distorção foi identificada na pesquisa realizada por Sergio Gobetti e Rodrigo Orair ${ }^{28}$, quando verificaram que a distribuição de renda no Brasil con-

26 OLIVEIRA, Fabrício Augusto de. Tributação e fisco no Brasil: avanços e retrocessos entre 1964 e 2010. In: CARDOSO JÚNIOR, José Celso; BERCOVICI, Gilberto (org.). República, democracia e desenvolvimento: contribuições ao Estado brasileiro contemporâneo. Brasília, DF: IPEA, 2013. p. 545.

27 SALVADOR, Evilásio. Fundo público e seguridade social no Brasil. São Paulo: Cortez, 2010. p. 212-213.

28 GOBETTI, Sergio Wulff; ORAIR, Rodrigo Octávio. Progressividade tributária: a agenda esquecida. Brasília, DF, 2015. Disponível em: http://www.esaf.fazenda.gov.br/premios/premios-1/premios-2015/xx-premio-tesouro-nacional-2015-pagina-principal/resultado-do-xx-premio-tesouro-nacional-2015. Acesso em: 15 nov. 2015. 
centra-se nos $10 \%$ mais ricos, $54,1 \%$ das rendas das famílias, enquanto no $1 \%$ concentra $24,5 \%$ e nos $0,01 \%$ detém $10,9 \%$ dessas rendas. Identificaram, ainda, que, no estrato dos $10 \%$ mais ricos, a progressividade se torna prejudicada, pois a alíquota cresce até o último centil de distribuição, atingindo 12,1\% (quem ganha entre R\$ 201 e R \$ 328 mil reais por ano) e cai para 7\% no estrato superior de $0,05 \%$ (quem ganha acima de 1,3 milhão por ano). A principal causa foi atribuída à isenção dos lucros e dividendos distribuídos aos sócios, concedida pela Lei n. 9.249, de 1995. Estima-se que, caso revogasse a isenção e voltasse a tributar, os ganhos do governo seriam entre R \$ 42 e R \$ 75 bilhões ao ano, além de proporcionar a progressividade mais justa. Ademais, Tomas Piketty ${ }^{29}$ já alertava sobre essa distorção, afirmando que, com a livre circulação de capitais e a concorrência fiscal das últimas décadas, os rendimentos do capital são cada vez menos tributados, escapando da progressividade dos impostos e, como consequência, a tributação fiscal vem se tornando regressiva no topo da hierarquia dos rendimentos, na maior parte dos países.

A mesma lei traz a remuneração dos sócios com "juros sobre o capital próprio" a uma tributação menor do que o trabalhador assalariado, violando o princípio da igualdade, além de permitir a dedução desses juros na apuração do IR e na CSLL.

No caso das renúncias fiscais, entre 1999 e 2014, aumentaram 1.288\%, com maior crescimento após 2008 com as medidas para socorrer o capital privado, destacando-se as renúncias nas contribuições previdenciárias, que cresceram $275 \%$ e representaram metade das renúncias fiscais. Essas renúncias comprometem o orçamento da seguridade social. As renúncias fiscais (tributárias e previdenciárias) superam, em todos os anos, de 2000 a 2014, os recursos destinados individualmente para assistência social, saúde, trabalho, educação e cultura, urbanismo e habitação, desporto e lazer. Destaca-se que, em 2014, as renúncias fiscais superaram em $254 \%$ o orçamento para a saúde e em $349 \%$ o da assistência social, além de fechar um valor total de 5,85\% do PIB, superando o déficit fiscal daquele ano, estimado em 0,63\% do PIB. Já em 2008, essa diferença era de 219\% e 109\%, respectivamente, e, em 2014, de R $\$ 306.854$ bilhões, o que quase alcançou a soma de todos os recursos destinados ao orçamento social ( $\mathrm{R} \$ 309.378$ bilhões) ${ }^{30}$.

Mesmo com o crescimento das renúncias, a carga tributária mantém-se em ascensão, demonstrando uma maior oneração para a categoria que ganha menos,

29 PIKETTY, Thomas. O capital no século XXI. Tradução de Sarah Adamopoulos. Lisboa: Temas e Debates, 2014. p. 749-750.

30 MAZZA, Willame Parente. Estado e Constituição: crise financeira, política fiscal e direitos fundamentais. Rio de Janeiro: Lumen Juris, 2016. p. 259-260. 
uma vez que as renúncias se concentram sobre quem possui maior renda, mantendo a distorção do sistema tributário, que passou a ser instrumento para os ajustes fiscais.

A estrutura tributária, de maneira equivocada e desigual, favorece a tributação sobre o consumo, com 47,51\% sobre a arrecadação em média de 1995 a 2013 , e menor sobre a renda $(18,27 \%)$ e propriedade $(3,27 \%)$, com uma nítida prioridade ao capital financeiro. Quando se compara com países da OCDE, percebe-se que o Brasil possui a maior carga tributária sobre o consumo, registrando 18,8\% do PIB em 2012, enquanto a Suíça, por exemplo, tem 6,1\%. Já a tributação sobre a renda, lucro e ganho de capital, aparece com 6,4\% do PIB, que perde somente para a Turquia $(6,0 \%)$, enquanto na Dinamarca chega-se a $29,6 \%$ e na Noruega, a $20,3 \%{ }^{31}$.

As medidas de ajustes atingem os direitos sociais, mas mantém o Brasil entre os três países emergentes com maior despesa de juros nominais em relação ao PIB e um custo da dívida pública superior à média dos países da Europa (1,44\% do PIB), Ásia (2,05\% do PIB), América Latina (1,54\% do PIB) e também do G20 dos países emergentes ${ }^{32}$.

Esse valor dos custos da dívida compromete o que fica disponível para o fundo público no gasto com custeio, investimento e políticas sociais, uma vez que, segundo pesquisa do Instituto de Pesquisa Econômica Aplicada (IPEA) 33 , é necessário verificar, além da carga tributária bruta, a carga tributária líquida, após as transferências públicas e o custo total do endividamento do Estado, a fim de determinar a efetiva capacidade do gasto público no atendimento da oferta de bens públicos e da prestação de serviços ao conjunto da população. Assim, analisando-se o ano de 2007, o Brasil, comparando a carga tributária líquida, após as transferências públicas e pagamento de juros, com o Canadá, Polônia, Reino Unido, Alemanha, França, Itália, Grécia, Suécia, etc., apresentou a carga líquida de 13,1\%, a menor entre todos, superando apenas a Grécia.

${ }^{31}$ MAZZA, Willame Parente. Estado e Constituição: crise financeira, política fiscal e direitos fundamentais, cit., p. 255.

32 BRASIL. Tribunal de Contas da União. Processo TC-028.192/2014-1, Grupo I, Classe V. Natureza: Levantamento. Interessado: Tribunal de Contas da União. Unidades: Secretaria do Tesouro Nacional do Ministério da Fazenda e Banco Central do Brasil. Relator: Min. José Múcio Monteiro. Brasília, DF, 22 de julho de 2015. Disponível em: http://portal3.tcu.gov.br/portal/ page/portal/TCU/imprensa/noticias/noticias_arquivos/028.192.2014.1\%20LEVANTAMENTO.\%20GESTÃO\%20DA\%20DÍVIDA.pdf. Acesso em: 1 dez. 2015.

33 INSTITUTO DE PESQUISA ECONÔMICA APLICADA (IPEA). Carga tributária líquida e efetiva capacidade do gasto público no Brasil. Brasília, DF, 2009. p. 9-20. 


\subsection{A seguridade social e o endividamento público: para onde foram os recursos orçamentários?}

A Constituição Federal de 1988 determinou um orçamento mínimo social para garantir os direitos sociais ao destacar os recursos vinculados para saúde, educação, erradicação da pobreza, fundo de amparo ao trabalhador, meio ambiente e a seguridade social. Consigna a seguridade social como direito do cidadão e dever do Estado, com orçamento próprio, a fim de garantir um conjunto de políticas públicas de assistência social, saúde e previdência em um sistema sustentado por um arcabouço financeiro que assegura esses direitos. Na verdade, a seguridade social é sustentada por toda a sociedade, por meio das contribuições sociais, pagas por trabalhadores e empresas; ou seja, utiliza-se de uma diversidade de fontes de recursos para proporcionar a crescente arrecadação e evitar a deterioração financeira do sistema, o que permite a sua sustentabilidade até em tempos de crise econômica.

Nesses termos, a seguridade social no Brasil é determinada pela Constituição, com um orçamento próprio e exclusivo, distinto daqueles que financiam as demais políticas do governo, de maneira que permite maior estabilidade ao sistema, diferenciando, inclusive, de outros países como Grã-Bretanha, Suécia e Itália, em que os serviços nacionais de saúde são financiados, quase na totalidade, por meio de impostos do orçamento fiscal. Nos países do norte da Europa (Dinamarca, Finlândia, Islândia, Noruega e Suécia), que guiam sua política econômica baseados nos ideais de igualdade com crescimento econômico e pleno emprego, o financiamento do sistema de proteção social se dá mediante impostos gerais, o que implica fortes redistribuições fiscais e acesso universal para todos os cidadãos. Nesses países, a forma de provisão pública de serviços de bem-estar é direta, em vez de ser por transferências monetárias, e os programas de bem-estar têm um perfil não discriminatório, não obedecendo a critérios seletivos de classes sociais ou de gênero ${ }^{34}$.

Ao contrário do que pensa o senso comum, um sistema estável de proteção social não compete ao sistema capitalista nem o contradiz, pelo contrário, reduz as instabilidades econômicas e melhora a eficiência do sistema, pelo que permite uma estabilização anticíclica em momento de desemprego, mantendo um elevado nível de demanda efetiva por meio do pagamento de pensões, aposentadorias, rendas mínimas e programas da assistência social, que geram uma maior estabilidade ao sistema capitalista ${ }^{35}$.

\footnotetext{
34 SALVADOR, Evilásio. Fundo público e seguridade social no Brasil, cit., p. 129.

35 SALVADOR, Evilásio. Fundo público e seguridade social no Brasil, cit., p. 119.
} 
O resultado financeiro da seguridade social é medido pelas receitas dessas contribuições, diminuída das despesas necessárias para manter o sistema. Destaca-se que, no período de 1995 a 2014, sempre se obteve superávit no sistema ${ }^{36}$. Muito se alega a crise financeira da previdência social, com suposto déficit, o que faz com que o governo justifique as contenções de gastos sociais com a classe trabalhadora ${ }^{37}$. Dessa forma, em importante estudo, Denise Lobato Gentil ${ }^{38}$ afirma que não há déficit na previdência social, mas saldo previdenciário negativo, sendo "a soma de receitas das contribuições ao INSS sobre a folha de salários e demais rendimentos do trabalho deduzidas dos benefícios previdenciários do RGPS”, não levando em consideração todas as receitas que deveriam ser computadas para ela, como estabelece o art. 195 da Constituição Federal, que dita seu orçamento próprio e exclusivo. $\mathrm{Na}$ verdade, perde-se o entendimento do conceito de seguridade social quando se excluem fontes de recursos do cálculo do resultado financeiro da Previdência.

Dessa forma, por apresentar comportamento superavitário, a seguridade social foi utilizada, usurpada a contribuir com a conta financeira e o desequilíbrio do orçamento fiscal, provocado pela política econômica de todos os governos que necessitavam pagar os juros e amortizações da dívida pública. Assim, essas despesas financeiras vêm crescendo no tempo, quando comparadas com as despesas previdenciárias. Considerando o ano de 1999, de severo ajuste fiscal do governo FHC, essas despesas chegaram a 7,9\% do PIB, fora o refinanciamento da dívida pública, que, se incluído, chegaria a 37,2\% do PIB. Já em 2006, 2007, 2008 e 2009 , esses valores foram de $12,7 \%, 10,3 \%, 10,2 \%$ e $11,8 \%$, respectivamente, e, com o refinanciamento da dívida, chegaram a 37,4\%, 26,6\%, 20,3\%, 20,1\%. Por outro lado, as despesas com os benefícios previdenciários não tiveram um crescimento significativo, embora tenham uma boa representatividade no orçamento, mantendo uma média de 6,8\% do PIB entre 1995 e $2013^{39}$.

Existe um evidente descontrole na política de renúncias fiscais, mormente as previdenciárias. Desde 2000, as renúncias fiscais sempre superaram os orçamentos sociais, com maior crescimento a partir de 2008 (pós-crise financeira). Essas

${ }^{36}$ MAZZA, Willame Parente. Estado e Constituição: crise financeira, política fiscal e direitos fundamentais, cit., p. 268.

${ }^{37}$ MAZZA, Willame Parente. Estado e Constituição: crise financeira, política fiscal e direitos fundamentais, cit., p. 265.

38 GENTIL, Denise Lobato. A política fiscal e a falsa crise do sistema de seguridade social no Brasil: análise financeira do período recente. In: SICSÚ, João (org.). Arrecadação, de onde vem? E gastos públicos, para onde vão? São Paulo: Boitempo, 2007. p. 30.

39 MAZZA, Willame Parente. Estado e Constituição: crise financeira, política fiscal e direitos fundamentais, cit., p. 270. 
desonerações foram resultadas das renúncias desmedidas, em diversos setores da economia, ao Plano Brasil Maior, com foco nas contribuições sociais, mormente as previdenciárias, com a desoneração da folha de pagamento.

As renúncias fiscais aumentaram, em valores nominais, $1.288 \%$ no período de 1999 a 2014, percebendo-se um maior aumento no período pós-crise de 2008, no qual as renúncias ficaram, em média, $\mathrm{R} \$ 165.923$ bilhões, de 2008 a 2014, enquanto de 1999 a 2007, estiveram, em média, em R \$ 38.224 bilhões. Tomando-se o período de 2008 a 2014 (pós-crise de 2008), as renúncias fiscais totais (tributárias e previdenciárias) aumentaram $236 \% \%$, e só as correspondentes às contribuições previdenciárias subiram $275 \%{ }^{40}$.

A desoneração da folha reflete nas renúncias das contribuições previdenciárias, que passaram a ser contabilizadas a partir de 2012, representando $4,12 \%$ das renúncias previdenciárias, aumentando para $26,77 \%$ em 2014. Devido a essa desoneração e às perdas na arrecadação federal, a lei prevê uma compensação de recursos na Conta Única do Tesouro, a fim de evitar o desequilíbrio nas contas do RGPS e os prejuízos financeiros para o financiamento da seguridade social ${ }^{41}$. No entanto, o governo não consegue “(...) compensar adequadamente o caixa da previdência social com a perda das receitas decorrentes da desoneração da contribuição patronal sobre a folha de pagamento" ${ }^{42} \mathrm{e}$, consequentemente, ao fato de o Tesouro Nacional arcar com essas "eventuais perdas" da desoneração da folha, compromete-se a capacidade de liberar outros recursos que poderiam ser utilizados como investimentos da saúde, assistência e previdência social ${ }^{43}$.

Segundo estudo da Associação Nacional dos Auditores Fiscais da Receita Federal do Brasil (Anfip) ${ }^{44}$, essa compensação não acontece, causando um desa-

${ }^{40}$ MAZZA, Willame Parente. Estado e Constituição: crise financeira, política fiscal e direitos fundamentais, cit., p. 256.

41 SINDICATO NACIONAL DOS AUDITORES-FISCAIS DA RECEITA FEDERAL DO BRASIL (SINDIFISCO NACIONAL). As renúncias tributárias federais e algumas repercussões econômicas. Brasília, DF: Diretoria de Estudos Técnicos, 2014. p. 12-13.

${ }^{42}$ SALVADOR, Evilásio. As consequências das renúncias tributárias no financiamento da Seguridade Social no Brasil. Revista Política Social e Desenvolvimento, [s.1.], n. 19, p. 17, maio 2015. Disponível em: http://plataformapoliticasocial.com.br/as-consequencias-das-renuncias-tributarias-no-financiamento-da-seguridade-social-no-brasil/. Acesso em: 3 jun. 2015.

43 SINDICATO NACIONAL DOS AUDITORES-FISCAIS DA RECEITA FEDERAL DO BRASIL (SINDIFISCO NACIONAL), As renúncias tributárias federais e algumas repercussões econômicas. Brasília, DF: Diretoria de Estudos Técnicos, 2014. p. 14.

${ }^{44}$ ZANGHELINI, Airton Nagel; MAÇANEIRO, Vanderley José (org.). Desoneração da folha de pagamento: oportunidade ou ameaça? 2. ed. Brasília, DF: ANFIP, Fundação ANFIP de Estudos da Seguridade Social, 2013. p. 63. 
juste no equilíbrio financeiro do sistema previdenciário. Para agravar a situação, a imprensa sempre aponta para o crescimento do "déficit" previdenciário e, juntamente com o governo, divulga dados que justificam a não implementação de mudanças que beneficiariam os segurados e para "justificar reformas pela supressão de direitos ou ampliação de carências”. Inclusive, quando se divulgam os relatórios da previdência em que estão presentes as renúncias, já não se colocam mais os efeitos decorrentes da desoneração da folha de pagamento, sob o argumento de que já estão compensados pela cobertura do Tesouro.

Sempre gerou grande discussão o verdadeiro destino dos recursos arrecadados para a política da seguridade social. Os recursos que deveriam ser empregados exclusivamente na seguridade social não são totalmente destinados a fins constitucionais. A DRU (Desvinculação das Receitas da União) - sucessora do FSE (Fundo Social de Emergência, EC n. 01/94) e do FEF (EC n. 10/96 e EC n.17/97) - caracterizou-se como um verdadeiro desvio de finalidades dos valores que seriam vinculados aos direitos sociais (saúde, educação, etc.). A DRU foi estabelecida pela EC n. 42/03, que alterou o ADCT, no art. 76, passando a permitir a desvinculação de órgão, fundo ou despesa, no período de 2003 a 2007, de 20\% da arrecadação da União de impostos, contribuições sociais e de intervenção no domínio econômico. Tem-se, ainda, que a DRU vem sendo prorrogada constantemente por todos os governos pelas EC n. 56/07, n. 68/11, sendo a última emenda a EC n. 93/2016, que aumentou o percentual de desvinculação para $30 \%$ e prorrogou até 2023.

Com isso, a DRU passa a exercer, como principal função, o desvio de recursos da saúde, educação, previdência e assistência social, transferidos do orçamento fiscal para os mercados financeiros. Estima-se que, na educação, a DRU, em 12 anos (1994 a 2006), desvinculou R 72 bilhões e que, apenas no período de 2000 a 2007, R \$ 45,8 bilhões deixaram de ser aplicados no setor. Assim, dos $18 \%$ que deveriam ser destinados à educação, conforme a Constituição Federal, são, após a retirada da DRU, aplicados somente 13\%. Já em relação à seguridade social, no período de 2000 a 2007, foram transferidos para o orçamento fiscal, por meio da DRU, R \$278,4 bilhões, que pertenciam às políticas do setor, um valor que equivaleria a cinco vezes o orçamento anual da saúde e quase dez vezes o da assistência social. Esses recursos, retirados pela DRU da seguridade social, têm participação relevante na composição do superávit primário ${ }^{45}$.

O economista Evilásio Salvador ${ }^{46}$ destaca que parte dos recursos da seguridade social é destinada, de maneira incorreta, para o pagamento dos benefícios

\footnotetext{
45 SALVADOR, Evilásio. Fundo público e seguridade social no Brasil, cit., p. 370 e 377.

46 SALVADOR, Evilásio. Fundo público e seguridade social no Brasil, cit., p. 259-260.
} 
previdenciários dos servidores públicos federais. Com efeito, a União transfere ao orçamento da seguridade social gastos com aposentadorias e pensões dos servidores federais contabilizadas como encargos previdenciários da União que deveriam ser alocados no orçamento fiscal. Em 2007, segundo Salvador, essas despesas com inativos e pensionistas da União totalizaram $\mathrm{R} \$ 50,3$ bilhões, sendo $\mathrm{R} \$ 17,8$ bilhões cobertos por receitas advindas das contribuições da União para o RPPS, da contribuição previdenciária dos servidores e da contribuição para custeio da pensão dos militares. O restante de $\mathrm{R} \$ 32,5$ bilhões foi coberto com as receitas do COFINS e CSLL, que deveriam financiar o orçamento próprio da seguridade social.

No mesmo sentido, destaca Denise Lobato Gentil ${ }^{47}$ que a União não usa o orçamento fiscal para fazer a contrapartida previdenciária como empregadora, socorrendo-se do orçamento da seguridade social, que é universal e para todos os cidadãos. No entanto, esse procedimento foi legalizado no governo de FHC, em 1998, quando alterou o art. 17 da Lei n. 8.212, permitindo que os encargos previdenciários sejam pagos pelos recursos da seguridade social que incidem sobre o COFINS e a CSLL.

Todavia, não se quer afirmar que não se necessita de mudanças no orçamento ou de projetos para solucionar a crise. Mas devem-se analisar as prioridades nas mudanças e preservar as conquistas sociais e os direitos fundamentais, uma vez que as escolhas orçamentais tomadas pelas decisões políticas devem ser conforme os valores da sociedade. Desse modo, analisando o orçamento federal, tomando por base os anos de 1994 a 2014, a dívida pública se mantém acima de $40 \%$, enquanto as destinações à parte social (saúde, educação, assistência social, saneamento, trabalho etc.) ficam em torno de $11 \%{ }^{48}$. Só para "juros e encargos da dívida”, em 2014, foram pagos R $\$ 170$ bilhões, afora amortizações e refinanciamento, com $3,98 \%$ para a saúde e $3,73 \%$ para a educação. Percebe-se a prioridade dos recursos públicos ao capital financeiro, o que direciona as reformas, a fim de manter este parâmetro "blindando" o sistema da dívida pública e "sufocando" os direitos sociais. A dívida pública goza de privilégios jurídicos, como se destaca no art.116, II, da Constituição Federal, que proíbe emendas parlamentares aos serviços da dívida, além de liberar a indicação de recursos necessários. Tem-se ainda a Lei de responsabilidade fiscal, que permite o contingenciamento dos gastos sociais, desde que não deixem de pagar os que se referem aos serviços

47 GENTIL, Denise Lobato. A política fiscal e a falsa crise do sistema de seguridade social no Brasil: análise financeira do período recente, cit., p. 34.

${ }^{48}$ MAZZA, Willame Parente. Estado e Constituição: crise financeira, política fiscal e direitos fundamentais, cit., p. 312. 
da dívida. Devido à falta de clareza na gestão da dívida pública, o Tribunal de Contas da União (TCU) concluiu em acórdão ${ }^{49}$ um levantamento da gestão da dívida pública federal, diagnosticando os seus riscos, entre irregularidades e falta de sustentabilidade, a fim de elaborar uma matriz de controle a curto e médio prazos. Ademais, entre possíveis irregularidades e possibilidades de redução da dívida, não se discute a auditoria da dívida pública, prevista no art. 26 do Ato das Disposições Constitucionais Transitórias (ADCT), que foi motivo, inclusive, da Arguição de Descumprimento de Preceito Fundamental (ADPF) n. 59, pelo não cumprimento do dispositivo constitucional.

\subsection{Uma visão dos gastos com proteção social}

Considerando dados da EUROSTAT ${ }^{50}$ e OCDE, os gastos com despesa pública são bastante expressivos em países desenvolvidos, permitindo-se afirmar a inexistência de estados que asseguram funções mínimas. A média dessas despesas em 27 países da União Europeia, em 2011, situava-se em 49,1\% do PIB, tendo sido 57,6\% na Dinamarca, 56\% na França, 55\% na Finlândia e 53,3\% na Bélgica. Se considerarmos somente as despesas públicas com proteção social, a média dos 27 países é de 19,6\% do PIB, sendo 25,2\% na Dinamarca, 23,9\% na França e $23,7 \%$ na Finlândia ${ }^{51}$.

No mesmo período de 2011, a despesa pública no Brasil foi de $16,8 \%$ do PIB e só com a proteção social foi de $8,4 \%$ do PIB $^{52}$. Assim, o padrão de gastos do Brasil com políticas de proteção social está muito aquém do que se gasta nos paí-

49 BRASIL. Tribunal de Contas da União. Processo TC-028.192/2014-1, Grupo I, Classe V. Natureza: Levantamento. Interessado: Tribunal de Contas da União. Unidades: Secretaria do Tesouro Nacional do Ministério da Fazenda e Banco Central do Brasil. Relator: Min. José Múcio Monteiro. Brasília, DF, 22 de julho de 2015. Disponível em: http://portal3.tcu.gov.br/portal/ page/portal/TCU/imprensa/noticias/noticias_arquivos/028.192.2014.1\%20LEVANTAMENTO.\%20GESTÃO\%20DA\%20DÍVIDA.pdf. Acesso em: 1º dez. 2015.

${ }_{50}$ EUROSTAT. Statistics Database. Disponível em: http://ec.europa.eu/eurostat/data/database. Acesso em: 2 fev. 2017.

51 ALVES, Nuno; MATA, João. O que dizem as estatísticas sobre a dimensão do estado. In: RODRIGUES, Maria de Lurdes; SILVA, Pedro Adão e (org.). Políticas públicas para a reforma do Estado. Coimbra: Almedina, 2013. p. 51-52.

52 SANTOS, Pedro Marcante Arruda dos et al. Relatório de Análise Econômica dos Gastos Públicos Federais: evolução dos gastos públicos federais no Brasil - uma análise para o período 2006-2015. Ministério da Fazenda: Secretaria de Política Econômica. Disponível em: http:// www.spe.fazenda.gov.br/notas-e-relatorios/relatorio_gasto_publico_federal_site.pdf. Acesso em: 2 jan. 2017. 
ses europeus. Percebe-se, portanto, que a reforma não deve passar necessariamente pelo corte dos gastos sociais e redução dos direitos, com o discurso da necessidade de se fazer o "sacrifício", mas deve-se verificar a qualidade dos gastos e levar em consideração os indicadores de desempenho e multiplicadores que darão uma resposta na economia.

Nesse diapasão, destaca-se o trabalho de Rodrigo Octávio Orais, Fernando de Faria Siqueira e Sergio Wulf Gobetti, premiado no XXI Prêmio Tesouro Nacional 2016, Política Fiscal e Ciclo Econômico: uma análise baseada em multiplicadores do gasto público ${ }^{53}$. Os pesquisadores analisaram o impacto dos gastos públicos dentro dos ciclos econômicos. Dito de outra forma, verificaram os multiplicadores dos diferentes tipos de gastos públicos dentro da economia em expansão e em recessão, com o objetivo de constatar o comportamento dos multiplicadores fiscais ao longo do ciclo econômico. Na tabela abaixo, retirada do trabalho, extraem-se algumas conclusões para a política fiscal no Brasil.

\section{Multiplicadores para o aumento de $\mathrm{R} \$ 1,00$ para o gasto do governo $0^{54}$}

\begin{tabular}{|l|c|c|c|}
\hline & LINEAR & EXPANSÃo & RECESSÃo \\
\hline Benefícios Sociais & 0,8416 & 0,1536 & 1,5065 \\
\hline Ativos Fixos & 1,0414 & 0,1623 & 1,6806 \\
\hline Subsídios & 1,5013 & 4,7338 & 0,5972 \\
\hline Gasto de Pessoal & 0,6055 & 0 & 1,3265 \\
\hline
\end{tabular}

Observa-se que, em situação de forte depressão econômica, o efeito de alguns gastos, como benefícios sociais e pessoal, é expressivo quando comparado ao ciclo econômico de expansão. Assim, no período de recessão, para cada R \$ 1,00 gasto em benefícios sociais pelo governo, encontra-se um multiplicador de 1,5065 , portanto um valor expressivo a ser considerado, em tempos de corte de

53 ORAIR, Rodrigo Octávio; SIQUEIRA, Fernando de Faria; GOBETTI, Sergio Wulff. Política fiscal e ciclo econômico: uma análise baseada em multiplicadores do gasto público. XXI Prêmio Tesouro Nacional 2016. Disponível em: http://www.tesouro.fazenda.gov.br/documents/10180/558095/2o-lugar-rodrigo-octavio-orair-086.pdf/ff2dc598-149a-419d-b95f-fb6e54e10d4f. Acesso em: 2 jan. 2017.

${ }^{54}$ ORAIR, Rodrigo Octávio; SIQUEIRA, Fernando de Faria; GOBETTI, Sergio Wulff. Política fiscal e ciclo econômico: uma análise baseada em multiplicadores do gasto público. XXI Prêmio Tesouro Nacional 2016. Disponível em: http://www.tesouro.fazenda.gov.br/documents/10180/558095/2o-lugar-rodrigo-octavio-orair-086.pdf/ff2dc598-149a-419d-b95f-fb6e54e10d4f. Acesso em: 2 jan. 2017. 
gastos sociais, mormente nos períodos atuais de recessão. Da mesma forma, gastos com subsídios dados pelo governo em períodos de recessão, como aconteceu com o Brasil a partir de 2011, deram uma resposta com multiplicadores de 0,5972, inferiores à unidade. Nesse caso, os autores concluíram que "o achado de que os multiplicadores associados aos subsídios não são significativos ou persistentes em qualquer posição do ciclo ajuda a entender o insucesso da política fiscal em sustentar o crescimento econômico a partir de 2011, quando esse tipo de estímulo cresceu significativamente, via desonerações, empréstimos do BNDES e outros programas, em substituição aos investimentos públicos”.

Portanto, a política de gastos públicos deve considerar os ciclos econômicos com suas diversas espécies de gastos para analisar os impactos na economia, e não cortes lineares como realizados pela PEC 241/44 (teto dos gastos), que propõe uma redução rígida e sem válvula de escape em 20 anos, assim como a reforma da previdência, com o discurso da redução dos gastos previdenciários e seu pseudodéficit, que, na verdade, desmonta as conquistas de direitos sociais consagradas na nossa combalida Constituição Federal.

Estudo do Instituto de Pesquisa Econômica Aplicada (IPEA) ${ }^{55}$, intitulado Equidade fiscal no Brasil: impactos distributivos da tributação e dos gastos sociais, demonstra que o aumento dos gastos sociais no período de 2003 a 2009 contribuiu para a redução da desigualdade de renda no Brasil. Com o aumento dos benefícios previdenciário, assistenciais e o maior volume de recursos aplicado na saúde e educação, em 2003, por exemplo, o índice Gini, que mede o nível de desigualdade entre ricos e pobres, caiu de 0,548 para 0,496 , sendo que, quanto mais próximo de 1 , mais desigual é o país. O estudo destacou o acentuado perfil redistributivo dos gastos sociais entre 2003 e 2009. Assim, a injusta regressividade da tributação indireta que atinge com uma maior carga tributária as camadas pobres e intermediárias de renda é, de certa forma, compensada por recursos proporcionalmente maiores das políticas sociais. Dentre essas políticas, estão os benefícios à saúde e educação e os advindos do Regime Geral da Previdência Social.

\section{O DESENVOLVIMENTO ECONÔMICO E A PROGRESSÃO SOCIAL: MUITO ALÉM DA AUSTERIDADE, DOS AJUSTES FISCAIS E DA REDISTRIBUIÇÃO DE RENDA}

Nos itens anteriores, discutiu-se como o capital financeiro sequestrou a produtividade, por meio, entre outros instrumentos, de legislações que favoreceram

55 INSTITUTO DE PESQUISA ECONÔMICA APLICADA (IPEA). Equidade fiscal no Brasil: impactos distributivos da tributação e dos gastos sociais. Disponível em: http://www.ipea.gov.br/ portal/images/stories/PDFs/comunicado/110519_comunicadoipea92.pdf. Acesso em: 2 jan. 2017. 
o capital privado ao custo da redução dos direitos sociais. Alternativas como a austeridade, reformas radicais na legislação trabalhista, previdenciárias com redução profunda nos gastos sociais são colocadas como as únicas soluções para o desenvolvimento econômico. Argumenta-se ser necessário inicialmente proceder a esse conjunto de medidas para só depois se chegar à recuperação econômica, crescimento e o retorno do bem-estar social, com medidas induzidas prioritariamente pelo mercado.

O sistemático privilégio de recursos para o sistema financeiro para a blindagem da dívida pública e os ajustes fiscais seletivos prejudicaram a questão da redistribuição de renda e seguramente a redução das desigualdades. A reversão dessas consequências envolve uma interação e dinâmica entre os sistemas financeiros, tributários e orçamentários, notadamente, conjugados com os fundamentos e objetivos da Constituição Federal.

No entanto, assim como as medidas de austeridade não são a solução para o desenvolvimento econômico com progressão social e redistribuição de renda, essa interação e harmonia nos sistemas financeiro, orçamentário e tributário, embora extremamente essenciais, são insuficientes para o equilíbrio entre o desenvolvimento econômico com responsabilidade social.

Assim, não adianta ter bons mecanismos de distribuição de renda se não há produtividade e projetos para o crescimento a fim de desenvolver as forças produtivas e a produção de mercadorias de alto valor agregado.

É nesse sentido que se destaca importante e relevante estudo para a economia do físico Cesar Hidalgo (pesquisador do MIT) e o economista Ricardo Hausmann (pesquisador em Harvard), que combinaram tecnologias desenvolvidas pelo MIT Media Lab e Kennedy School de Harvard e desenvolveram o Atlas da Complexidade econômica, o mais relevante banco de dados de Big Data da economia, criado em 2011, que permite o acesso rápido a milhares de informações do comércio internacional desde 1960, cobrindo 6 mil produtos em 120 países ao longo de 50 anos.

Segundo pesquisas do economista da FGV Paulo Gala ${ }^{56}$, por meio do atlas é possível verificar uma relação direta entre o desenvolvimento econômico e a complexidade produtiva dos países. Dito de outra forma, o desenvolvimento se dá com a construção de complexidade, pelo que, quanto mais complexa a produção, com diversidade produtiva não ubíqua, produção de manufaturas high tech e

56 GALA, Paulo. Complexidade econômica: uma nova perspectiva para entender a antiga questão da riqueza das nações. Rio de Janeiro: Contraponto, 2017. p. 9-18. 
serviços sofisticados (finanças, advocacia, marketing, TI, design), mais rica é a nação. Portanto, com o aumento da complexidade, aumenta-se a possibilidade de divisão do trabalho dentro das empresas e entre as empresas, fazendo com que a economia passe a ser capaz de construir, de forma eficiente, redes produtivas em setores manufatureiros com retornos crescentes de escala e a volta ao capital produtivo. O objetivo nesse sistema é promover o pleno emprego, no qual aumente a produtividade em cada setor e haja a transferência de trabalhadores para a indústria que produz bens e serviços de maior valor agregado e paga maiores salários.

Países ricos e desenvolvidos como Alemanha, Japão, Coreia do Sul, EUA e Reino Unido cresceram não em razão das políticas de austeridade, mas pela complexidade econômica e produtividade. Atualmente, no Brasil, o setor que mais perde empregos é o industrial, considerado o setor que mais impulsiona a produtividade em uma economia, dado que, hoje, a indústria vem empregando poucos trabalhadores com alta produtividade. Vale dizer, "o processo de desenvolvimento econômico envolve, ou historicamente envolveu, mudanças na estrutura produtiva dos países, caracterizadas pela migração de trabalhadores de setores menos produtivos para setores mais produtivos" ${ }^{57}$. Assim, a produtividade tem um forte potencial de ser a condição para o desenvolvimento do país e para o pleno emprego. Como afirma Paulo Gala ${ }^{58}$ : "são ricos e desenvolvidos aqueles países capazes de produzir e vender no mercado mundial bens complexos e sofisticados, e pobres aqueles apenas capazes de produzir e vender coisas simples e rudimentares. Por isso o desenvolvimento econômico pode também ser entendido como a capacidade de uma sociedade de conhecer e controlar técnicas produtivas, especialmente nos mercados mundiais mais relevantes", o que atrai empregados qualificados e bem remunerados. Isso advém de uma alta produtividade, que produzirá salários mais altos, e não como se impõe nas políticas de austeridade, uma redução nos direitos/custos trabalhistas, com a consequente redução salarial e uma falsa ilusão de maior competitividade, produtividade para salvar a economia, ou seja, um "empobrecimento salvador".

Nesse mesmo sentido, conforme importante pesquisa desenvolvida por Cesar Hidalgo e outros pesquisadores em 2016, Linking Economic Complexity, Institutions and Income Inequality, a complexidade econômica reduz a desigualdade, ou seja, países mais complexos apresentam menores índices de desi-

57 SQUEFF, Gabriel Coelho; NEGRI, Fernanda de. Produtividade do trabalho e mudança estrutural no Brasil nos anos 2000. In: NEGRI, Fernanda de; CAVALCANTE, Luiz Ricardo (org.). Produtividade no Brasil: desempenho e determinantes. Brasília: ABDI, IPEA, 2014. v. 1, p. 249.

58 GALA, Paulo. Alemanha e Brasil: qual a diferença principal? Disponível em: https://www. paulogala.com.br/alemanha-e-brasil-qual-diferenca-principal/. Acesso em: 30 jun. 2017. 
gualdade social, com um coeficiente Gini ajustado por complexidade do tecido produtivo ${ }^{59}$.

É possível, portanto, gerar complexidade por meio de uma atuação conjunta entre Estado e Mercado, mediante a indução à inovação e criação de produtos complexos, somado à participação das universidades nas pesquisas, a fim de criar e disseminar conhecimento. Assim, como bem consolidado nas pesquisas da economista Mariana Mazzucato, o Estado passa a ter um papel empreendedor, auxiliando o setor privado a encontrar novas oportunidades rentáveis que contribuam ao desenvolvimento. Mazzucato ${ }^{60}$ afirma que receitas como austeridade só prejudicam, pois não é o tamanho agregado do setor público que importa, mas a qualidade com que se está gastando, como um sistema de saúde eficiente, funcional, educação de qualidade e pesquisas inovadoras que podem contribuir para a formação de capital humano e tecnologias futuras. Dessa forma, conforme Mazzucato, não importa tanto a relação da dívida com o PIB, uma vez que muitos países têm dívidas altas e gastam mal, não incentivando o crescimento a longo prazo.

\section{CONSIDERAÇÕES FINAIS}

A questão central que se discute hoje e na maior parte do século, como bem assevera Tony Judt ${ }^{61}$, são os debates implícitos ou explícitos sobre a ascensão do Estado, que levaram a questionar que espécie de Estado queriam as pessoas livres, que propósitos queriam que ele servisse e qual o preço que estavam dispostos a pagar.

Esses propósitos e fundamentos foram consignados nas constituições democráticas que traçaram um modelo de Estado democrático de direito, não como uma mera adaptação das condições sociais como previsto nos modelos anteriores, mas transformador da realidade, que tem na igualdade, formal e material, uma condição de possibilidade para alcançar as conquistas civilizatórias e de bem-estar.

Os fundos públicos são necessários para sustentar esse modelo democrático, dentro, seguramente, de uma responsabilidade das contas públicas. Acontece que esses fundos são desviados para atender às políticas de favorecimento do capital

${ }^{59}$ HIDALGO, Cesar; HARTMANN, M. R.; GUEVARA, C.; JARA-FIGUEROA, M. ARISTARÁN, C. A. Linking Economic Complexity, Institutions and Income Inequality. Disponível em: https://www.sciencedirect.com/science/article/pii/S0305750X15309876. Acesso em: 5 maio 2018.

${ }^{60}$ MAZZUCATO, Mariana. O estado empreendedor: desmascarando o mito do setor público vs. Setor privado. São Paulo: Portfolio-Penguin, 2014. p. 44.

${ }^{61}$ JUDT, Tony. Pensar o século XX. Lisboa: Edições 70, 2012. p. 384. 
financeiro e beneficiamento dos rentistas. Tais políticas, ditas de austeridade, focadas na estabilização financeira, nos ajustes fiscais e cortes nos gastos sociais, vêm sendo utilizadas como instrumento beneficiador do capital financeiro e necessárias ao pagamento das dívidas do capital. Para isso, utilizam mecanismos que alteram as estruturas jurídicas, fragilizam as soberanias locais, promovendo o desmonte do Estado social, por meio da diminuição da produção, dos direitos sociais, aumento do desemprego e na baixa dos salários reais.

Deve-se, portanto, conscientizar e democratizar os valores sociais, pois o bom funcionamento da democracia garante que as escolhas orçamentais tomadas pelas decisões políticas sejam conforme os valores da sociedade.

Destarte, as finanças públicas de um Estado devem conjugar a solidariedade social, com a eficácia e a tradição democrática, tendo o orçamento como o espelho da nação, para, por meio dele, retratarem-se as opções de política econômica e social. ${ }^{62}$

O desenvolvimento econômico com progressão social vai muito além de programas de austeridade, ajustes fiscais e beneficiamento do capital financeiro. É necessário um país produtivo, um Estado indutor da inovação, que permita uma relação simbiótica e não parasitária com o mercado, a fim de aumentar a produtividade, a complexidade econômica com diversidade produtiva e, consequentemente, a competitividade, só assim ter-se-ão recursos financeiros para distribuir e sustentar direitos conquistados nas constituições democráticas.

Ademais, é necessário que os sistemas financeiro, econômico e tributário funcionem alinhados aos princípios e normas da Constituição, que devem coordenar a construção daqueles sistemas, para garantir as questões sociais igualitárias previstas no Estado democrático de direito.

\section{REFERÊNCIAS}

ALVES, Nuno; MATA, João. O que dizem as estatísticas sobre a dimensão do estado. In: RODRIGUES, Maria de Lurdes; SILVA, Pedro Adão e (org.). Políticas públicas para a reforma do Estado. Coimbra: Almedina, 2013.

BERCOVICI, Gilberto. Soberania e Constituição: para uma crítica do constitucionalismo. São Paulo: Quartier, 2013.

BERCOVICI, Gilberto; MASSONETTO, Luís Fernando. A Constituição dirigente invertida: a blindagem da Constituição financeira e a agonia da Constituição económica. Boletim de Ciências Econômicas, Coimbra, v. 49, 2006.

${ }^{62}$ BOUVIER, Michel; LASSALE, Jean-Pierre et al. Finances Publiques. Paris: LGDJ, 2014. p. 30. 
BLANCHARD, Olivier; DELL'ARICCIA, Giovanni; MAURO, Paolo. Repensar la política macroeconômica. Revista de Economía Institucional, Bogotá, v. 12, n. 22, p. 66, 2010. Disponível em: http://www.economiainstitucional.com/pdf/no22/ oblanchard22.pdf. Acesso em: 24 fev. 2015.

BOUVIER, Michel; LASSALE, Jean-Pierre et al. Finances Publiques. Paris: LGDJ, 2014. BRASIL. Tribunal de Contas da União. Processo TC-028.192/2014-1, Grupo I, Classe V. Natureza: Levantamento. Interessado: Tribunal de Contas da União. Unidades: Secretaria do Tesouro Nacional do Ministério da Fazenda e Banco Central do Brasil. Relator: Min. José Múcio Monteiro. Brasília, DF, 22 de julho de 2015. Disponível em: http://portal3.tcu.gov.br/portal/page/portal/TCU/imprensa/noticias/noticias_ arquivos/028.192.2014.1\%20LEVANTAMENTO.\%20GESTÃO\%20DA\%20DÍVIDA. pdf. Acesso em: 1 dez. 2015.

DEPARTAMENTO INTERSINDICAL DE ESTATÍSTICA E ESTUDOS ECONÔMICOS (DIEESE). PEC $n$. 241/2016: o novo regime fiscal e seus possíveis impactos. Disponível em: https://www.dieese.org.br/notatecnica/2016/ notaTec161novoRegimeFiscal.pdf. Acesso em: 20 out. 2016.

EUROSTAT. Statistics Database. Disponível em: http://ec.europa.eu/eurostat/data/ database. Acesso em: 2 fev. 2017.

FITOUSSI, Jean-Paul. A democracia e o mercado. Tradução de Paulo Pedroso. Lisboa: Terramar, 2005.

GALA, Paulo. Alemanha e Brasil: qual a diferença principal? Disponível em: https://www. paulogala.com.br/alemanha-e-brasil-qual-diferenca-principal/. Acesso em: 30 jun. 2017.

GALA, Paulo. Complexidade econômica: uma nova perspectiva para entender a antiga questão da riqueza das nações. Rio de Janeiro: Contraponto, 2017.

GARCÍA-PELAYO, Manuel. As transformações do Estado contemporâneo. Tradução de Agassiz Almeida Filho. Rio de Janeiro: Forense, 2009.

GENTIL, Denise Lobato. A política fiscal e a falsa crise do sistema de seguridade social no Brasil: análise financeira do período recente. In: SICSÚ, João (org.). Arrecadação, de onde vem? E gastos públicos, para onde vão? São Paulo: Boitempo, 2007.

GOBETTI, Sergio Wulff; ORAIR, Rodrigo Octávio. Progressividade tributária: a agenda esquecida. Brasília, DF, 2015. Disponível em: http://www.esaf.fazenda.gov.br/ premios/premios-1/premios-2015/xx-premio-tesouro-nacional-2015-pagina-principal/ resultado-do-xx-premio-tesouro-nacional-2015. Acesso em: 15 nov. 2015.

GRAU, Eros Roberto. Resenha do prefácio da $2^{a}$ edição. In: COUTINHO, Jacinto Nelson de Miranda (org.). Canotilho e a constituição dirigente. São Paulo: Renovar, 2005.

HIDALGO, Cesar; HARTMANN, M. R.; GUEVARA, C.; JARA-FIGUEROA, M. ARISTARÁN, C. A. Linking Economic Complexity, Institutions and Income Inequality. Disponível em: https:/www.sciencedirect.com/science/article/pii/ S0305750X15309876. Acesso em: 5 maio 2018.

INSTITUTO DE PESQUISA ECONÔMICA APLICADA (IPEA). Carga tributária líquida e efetiva capacidade do gasto público no Brasil. Brasília, DF, 2009. 
INSTITUTO DE PESQUISA ECONÔMICA APLICADA (IPEA). Equidade fiscal no Brasil: impactos distributivos da tributação e dos gastos sociais. Disponível em: http:// www.ipea.gov.br/portal/images/stories/PDFs/comunicado/110519_comunicadoipea92. pdf. Acesso em: 2 jan. 2017.

JUDT, Tony. Pensar o século XX. Lisboa: Edições 70, 2012.

LEROY, Marc. Sociologia da decisão financeira pública. In: SANTOS, António Carlos dos; LOPES, Cidália Maria da Mota Lopes (coord.). Fiscalidade: outros olhares. Porto: Vida Econômica, 2013.

MASSONETTO, Luis Fernando. O direito financeiro no capitalismo contemporâneo: a emergência de um novo padrão normativo. 2006. 104f. Tese (Doutorado em Direito) - Universidade de São Paulo, São Paulo, 2006.

MAZZA, Willame Parente. Estado e Constituição: crise financeira, política fiscal e direitos fundamentais. Rio de Janeiro: Lumen Juris, 2016.

MAZZUCATO, Mariana. O estado empreendedor: desmascarando o mito do setor público vs. Setor privado. São Paulo: Portfolio-Penguin, 2014.

MORAIS, José Luis Bolzan. Entre o Estado social e a transformação social: mudar para não mudar. In: COUTINHO, Adalcy et al. (org.). Liber Amicorum: homenagem ao Prof. Doutor António José Avelãs Nunes. Coimbra: Coimbra Editora, 2009.

MORAIS, José Luis Bolzan. O Brasil pós-1988: dilemas do/para o Estado constitucional. In: SCAFF, Fernando Facury (org.). Constitucionalizando direitos: 15 anos da Constituição brasileira de 1988. Rio de Janeiro: Renovar, 2003.

MORAIS, José Luis Bolzan. O Estado e seus limites: reflexões iniciais sobre a profanação do Estado social e a dessacralização da modernidade. In: OLIVEIRA NETO, Francisco José de et al. Constituição e Estado social: os obstáculos à concretização da Constituição. Coimbra: Coimbra Editora; São Paulo: RT, 2008.

NUNES, António José Avelãs. Apontamento sobre a origem e a natureza das políticas de austeridade. In: FERREIRA, Eduardo Paz (coord.). A austeridade cura? A austeridade mata? Lisboa: AADFL, 2014.

NUNES, António José Avelãs. O aprofundamento da crise estrutural do capitalismo e a integração capitalista europeia. Empório do Direito, [s.1.], 4 abr. 2015. Disponível em: http://emporiododireito.com.

br/o-aprofundamento-da-crise-estrutural-do-capitalismo-e-a-integracao-capitalistaeuropeia-por-antonio-avelas-nunes/. Acesso em: 5 abr. 2015.

OLIVEIRA, Fabrício Augusto de. Tributação e fisco no Brasil: avanços e retrocessos entre 1964 e 2010. In: CARDOSO JÚNIOR, José Celso; BERCOVICI, Gilberto (Org.). República, democracia e desenvolvimento: contribuições ao Estado brasileiro contemporâneo. Brasília, DF: IPEA, 2013.

ORAIR, Rodrigo Octávio; SIQUEIRA, Fernando de Faria; GOBETTI, Sergio Wulff. Política fiscal e ciclo econômico: uma análise baseada em multiplicadores do gasto público. XXI Prêmio Tesouro Nacional 2016. Disponível em: http://www.tesouro. 
fazenda.gov.br/documents/10180/558095/2o-lugar-rodrigo-octavio-orair-086.pdf/ ff2dc598-149a-419d-b95f-fb6e54e10d4f> Acesso em: 2 jan. 2017.

PIKETTY, Thomas. O capital no século XXI. Tradução de Sarah Adamopoulos. Lisboa: Temas e Debates, 2014.

RECEITA FEDERAL. Brasília, DF, 2015. Disponível em: www.receita.fazenda.gov. br>. Acesso em: 10 abr. 2015.

REZENDE, Fernando; OLIVEIRA, Fabrício; ARAÚJO, Erika. O dilema fiscal: remendar ou reformar? Rio de Janeiro: FGV, 2007.

ROMÃO, António. A crise "mata”, a austeridade “enterra”. In: FERREIRA, Eduardo Paz (coord.). A austeridade cura? A austeridade mata? Lisboa: AADFL, 2014.

SALVADOR, Evilásio. As consequências das renúncias tributárias no financiamento da Seguridade Social no Brasil. Revista Política Social e Desenvolvimento, [S.1.], n. 19, p. 17, maio 2015. Disponível em: http://plataformapoliticasocial.com.br/as-consequenciasdas-renuncias-tributarias-no-financiamento-da-seguridade-social-no-brasil/. Acesso em: 3 jun. 2015.

SALVADOR, Evilásio. Fundo público e seguridade social no Brasil. São Paulo: Cortez, 2010.

SANTOS, Pedro Marcante Arruda dos et al. Relatório de Análise Econômica dos Gastos Públicos Federais: evolução dos gastos públicos federais no Brasil - uma análise para o período 2006-2015. Ministério da Fazenda: Secretaria de Política Econômica. Disponível em: http://www.spe.fazenda.gov.br/notas-e-relatorios/relatorio_gasto_ publico_federal_site.pdf. Acesso em: 2 jan. 2017.

SINDICATO NACIONAL DOS AUDITORES-FISCAIS DA RECEITA FEDERAL (UNAFISCO SINDICAL). Nota técnica n. 6: a arrecadação e o destino dos recursos da CPMF. Brasília, DF, 2007.

SINDICATO NACIONAL DOS AUDITORES-FISCAIS DA RECEITA FEDERAL DO BRASIL (SINDIFISCO NACIONAL). As renúncias tributárias federais e algumas repercussões econômicas. Brasília, DF: Diretoria de Estudos Técnicos, 2014.

SQUEFF, Gabriel Coelho; NEGRI, Fernanda de. Produtividade do trabalho e mudança estrutural no Brasil nos anos 2000. In: NEGRI, Fernanda de; CAVALCANTE, Luiz Ricardo (org.). Produtividade no Brasil: desempenho e determinantes. Brasília: ABDI, IPEA, 2014. v. 1.

STIGLITZ, Joseph. "Ajuste fiscal”? por que não seguir a Europa. Tradução de Mariana Bercht Ruy. [s.1.], 12 nov. 2014. Disponível em: http://brasildebate.com.br/ ajuste-fiscal-por-que-nao-seguir-a-europa/. Acesso em: 12 nov. 2014.

STREECK, Wolfgang. Tempo comprado: a crise adiada do capitalismo democrático. Tradução de Marian Toldy e Teresa Toldy. Lisboa: Actual, 2013.

ZANGHELINI, Airton Nagel; MAÇANEIRO, Vanderley José (org.). Desoneração da folha de pagamento: oportunidade ou ameaça? 2. ed. Brasília, DF: ANFIP, Fundação ANFIP de Estudos da Seguridade Social, 2013. 